\title{
Impact of Consumers' Preference for Cultural and Creative Parks on the Attitude Behavior Model
}

\author{
Shwu-Ing $\mathrm{Wu}^{1} \&$ Man-Li Tian ${ }^{1}$ \\ ${ }^{1}$ Department of Business Administration, National Chin-Yi University of Technology, Taiwan, Republic of \\ China \\ Corresponding: Shwu-Ing Wu, Department of Business Administration, National Chin-Yi University of \\ Technology, No. 57, Section 2, Zhongshan Road, Taiping, Taichung, Taiwan 411, R.O.C. Tel: 886-4-2392-4505. \\ E-mail: wusi@ncut.edu.tw
}

Received: April 24, 2017

Accepted: June 24, 2017

Online Published: July 18, 2017

doi:10.5539/ijbm.v12n8p201

URL: https://doi.org/10.5539/ijbm.v12n8p201

\begin{abstract}
In recent years, Taiwan has actively developed cultural and creative industries, expanded the scale of the national consumer market, and launched international tourism; therefore, diverse Cultural and Creative Parks have appeared. However, what are the characteristics of Cultural and Creative Parks that attract consumers and change their attitude and behavior? The answers to such questions rely on further study. This study focuses on Cultural and Creative Parks to determine whether the various characteristics of Cultural and Creative Parks in Taiwan lead to attraction to the parks and influence the consumers' attitude model, in order to propose useful decision-making information for Cultural and Creative Parks. By investigating 788 valid questionnaires according to preference degree for Cultural and Creative Parks, this study divides consumers into two groups and compares the group models. According to the findings: (1) in comparison to consumers that do not prefer Cultural and Creative Parks, those who enjoy Cultural and Creative Parks show more significant impact of cultural creative products, creative markets, and performance activities on attraction to Cultural and Creative Parks; (2) in comparison to consumers that do not prefer Cultural and Creative Parks, those who enjoy Cultural and Creative Parks show more significant intensity on path of attraction of Cultural and Creative Parks to behavior to visit; (3) consumers that do not prefer Cultural and Creative Parks have more significant impact on the relationship between cognition, behavior, and affection regarding attitude in the CBA model.
\end{abstract}

Keywords: Cultural and Creative Park, attraction, CBA attitude model

\section{Introduction}

\subsection{Research Background and Motives}

In recent years, voluntary creative capacity in Taiwan is continuously accumulated. The potential of cultural and creative industries that combine various creative elements are generally valued by different fields, and the construction of Cultural and Creative Parks is an example (Ministry of Culture, 2014). Cultural and Creative Parks (called Wen Chuang Yuan Qu) are areas with complete organization, specific instructions, and multiple uses, which proposes night activities, extends the usage time of the area to reinforce such attraction, and provides the conditions required by artistic organizations and art activities for residents and tourists. Moreover, it offers more job opportunities to local artists to closely connect art with community development (Frost-Kumpf, 1998).

Montgomery (2003; 2004) indicated the characteristics of Cultural Quarters, as follows: historic traces, knowledge, design style, innovation and change, multi-usage land, activity diversity, and a night economy through food culture and educational places. Regarding construction, it requires consistent street views and the ability to coordinate economy, culture, and society.

Currently, Cultural and Creative Parks planned in Taiwan include five elements; Cultural and Creative Parks in Taipei, Taichung, Chiayi, Tainan, and Hualien are the reconstruction of old liquor factories and warehouses, which reuse idle spaces as art performing spaces and cross-field exchange platforms, thus, it revives old buildings with the mission to restore them (Ministry of Culture, 2013).

There are two types of Cultural and Creative Parks in Taiwan. One is the reconstruction of old warehouses and 
factories, which mainly combine the characteristics of buildings and historic atmospheres with cultural creative demands. The other is the modern industrial park. The main characteristics of the top five Cultural and Creative Parks in Taiwan are, as follows: the Taichung Cultural \& Creative Industries Park cultivates public spatial aesthetics through architecture design and art; the Chiayi Cultural \& Creative Industries Park values an innovation center of traditional art; the Tainan Cultural \& Creative Industries Park is the integration of cultural life and industrial environment; the Songshan Cultural \& Creative Park is based on the design field, cultural art, and society; the Huashan 1914 Creative Park focuses on the presentation of cross-field art; the Hualien Cultural \& Creative Industries Park offers a window of eastern culture, as based on ecology and life (Yahoo News, 2015).

Based on the previous content of Cultural and Creative Parks, the characteristics can be classified into the following: cultural creative products, historic building and historic monuments, creative markets, and performing activities. These four characteristics are the sources of attraction of Cultural and Creative Parks, and are the main independent variables of this study.

"Attraction" is tourists' and recreationists' basic motivation to visit destinations. The prior goal to plan and construct Cultural and Creative Parks was to enhance quality of life. Lew (1987) suggested that the attractions of tourism sites consist of landscapes, participation, memories, and service and facilities, which can satisfy tourism participation; therefore, the establishment of attractions become relatively important (Victor, 1989). Consumers' perceptions of the attractions of Cultural and Creative Parks can influence their attitude and behavior, thus, it should be further studied.

According to Breckler (1984), the structure of attitude can be divided into three elements: cognition, affect, and behavior. Solomon (2002) proposed the low involvement effect (CBA) attitude model, and suggested a causal relationship among cognition, affection, and behavior. In the field of consumer behavior, attitude is the orientation of learning, which shows a preference for the targets. Therefore, consumer perception of the attractions of Cultural and Creative Parks becomes their attitude toward the parks, which is the key point of this study, thus this study applies the CBA model to research Cultural and Creative Parks.

Will the characteristics of Cultural and Creative Parks attract consumers and change their attitude and behavior? This is an issue that should be urgently explored by Cultural and Creative Parks. Therefore, this study focuses on Cultural and Creative Parks in Taiwan to determine if the characteristics of Cultural and Creative Parks are attractive, and thus, influence the consumers' attitude (CBA) model. This study explores whether consumers' preference for Cultural and Creative Parks will influence the attitude behavior model to construct a competing model, clusters consumers according to their preference for Cultural and Creative Parks, and compares the differences of the correlation models, in order to propose useful decision-making information for Cultural and Creative Parks.

\section{Literature Review}

\subsection{Cultural and Creative Park}

Cultural and Creative Parks are places for cultural enterprises and independent creative individuals, and have significant geographic areas, including cultural industries and highly concentrated facilities. In such parks, there are entertainment places for children, libraries, and open and informal entertainment sites (Bianchini, 1993).

Cultural and Creative Parks transform originality into cultural creative products with economic value. Cultural creative products are based on intellectual property rights. The construction of a brand supports local creative development (Santagata, 2006). Frost-Kumpf (2001) suggested that Cultural and Creative Parks are areas with complete organization, specific instruction, and multiple uses, which extend the use time of the area to reinforce the attraction, proposes artistic activities to residents and tourists, provides more job and residential opportunities to local artists, and closely connects art and community development.

Cultural and Creative Parks can result in creative life circles, meaning buildings or certain areas in a city have software and hardware environments, and continuously create ideas and innovative inventions, where various groups, such as artists, managers, intellectuals, and social movement participants can interact with each other and create new things or products to trigger economic growth (Landry, 2000).

\subsection{Cultural Creative Products}

The term "Culture" includes the life styles of society, the development of intelligence, and the practice of art, and connects personal cultural development and the social environments of the time (Throsby, 2001). Williams (1981) suggested that culture is the description of specific life styles, which indicate the values of art and concepts, and convey the value of daily life. Therefore, culture belongs to the public, and consists of peoples' daily life practices. 
In the trend of globalization, cultural dispersion can trigger cultural reflection and identification, and designers develop identifiable products with cultural features according to their own culture (Lin, 2009). Therefore, the rich content of local culture becomes the originality of product design. Designers obtain cultural elements, and by design, embed culture in their products to convey cultural value (Moalosi, Popovic \& Hickling, 2010).

Cultural creative products mainly embed cultural characteristics in the products to reinforce consumers' cultural consumption and product experience (Handa,1999; Yair, Press, \& Tomes, 2001; Yair, Tomes \& Press, 1999), thus, it gradually increases cultural value in global product markets (Lin,2009).

\subsection{Historic Buildings and Monuments}

The Council for Cultural Affairs, Executive Yuan, focus on idle spaces with historic significance and revive buildings, spaces, and environments for reuse, in order to transform them into local cultural sites. It implements overall planning, reinforcement of building structures, spatial reconstruction, and revival, and introduces local art groups and cultural and historic workers to stimulate local culture and the development of cultural heritage tourism (Council for Cultural Affairs, Executive Yuan, 2004).

Heritage Tourism is a process that combines recreation, entertainment, and educational functions (Herbert,1995). The research of Borg et al. (1996), regarding the top seven historic/artistic cities in Europe (Aix-en-Provence, Amsterdam, Bruges, Florence, Oxford, Salzburg \& Venice), suggested that the rise or declination of city tourism influences local economy, and is directly associated with the maintenance of historic heritage sites and quality of life for city residents. Hence, the rise of cultural and historic tourism is an important measure to revive historic and cultural cities (Chang, et al. 1996).

In order to reuse historic buildings, Cultural and Creative Parks in Taiwan have different building characteristics: (1) the Huashan 1914 Creative Park presents cross-field art and life aesthetics; (2) the Taichung Cultural \& Creative Industries Park is based on cultural creativity and cultural resources, and is supported by business. The goal is to revive old historic buildings and connect Taiwan with the global architecture design industry (Ministry of Culture, 2014).

\subsection{Creative Market}

Creative markets are bazaars that sell creative, fashionable, and original goods with little quantity and commercial value, and the products are generally presented by stands and kiosks (Whitt, 1987). In early times, bazaars mostly sold second-hand goods, which later became platforms to present and sell works of artistic creation, thus, they are transformed from the original "flea market" to "air-fairs". Well-known creative global markets are Spitalfields Market, the Up Market, and the Portobello Market of London, which are located in the United Kingdom. Therefore, flea markets, art-fairs, and creative markets are related.

Markets, night markets, creative markets, street markets, and evening market are common culture in Asian countries, such as Thailand, Taiwan, Hong Kong, Vietnam, and Malaysia, and the public are fond of shopping in such markets (Kuo, Huan, Thongma, Guntoro, Tsai, \& Chen, 2011; Maruyama \& Trung, 2010; Zain \& Rejab, 1989).

In short, creative markets display the stands of many creators, who sell their creative goods to consumers. As they exchange with other creators in the market, such markets are not simply places to sell goods, but are locations for cultural exchange (Wu \& Tian, 2016).

\subsection{Performing Activities}

Webster (1944) suggested that art is making or doing to present forms, beauty, or unique perceptions. According to the definition of The Oxford Dictionary of Art, performing art is an art form combining theatre, music, and visual art; by artificial arrangement, and upon the principle of beauty, it demonstrates thoughts, affection, and value to audiences through actions ( $\mathrm{Li}$ and Hsu, 2012). Billington (1981) suggested that performing art included large-stage performances, such as stage dramas, operas, ballets, musical plays, and small scale and warm performances, such as puppet plays, small theater, or folk theater. Saleh and Ryah (1993) indicated that the characteristics of performing activities aim to strengthen tourists' participation, and program contents include neighborhood features.

At present, the performing art policy in Taiwan aims to enhance the balanced development of performing art environments, cultivate art talents, and increase audiences. The support of sustainable operations of performing groups in Taiwan reinforces professional creation and performance levels to upgrade the competitiveness of national culture (Ministry of Culture, 2016).

Successful art activities strengthen the development of cultural creative industries and enhance the urban image 
and international competence of cities. Therefore, the performance activities of Cultural and Creative Parks can attract visitors, while the planning of thematic performance activities and cultural experiences can trigger local development (Ministry of Culture, 2013).

\subsection{Attractions of Cultural and Creative Parks}

"Attraction" refers to objects that are attracted by certain types of information, and spread by subjects with or without intention, meaning participants actively approach it or take action. When there are tourism resources, artificial uniqueness, or unique services or facilities that satisfy tourism needs and enhance tourism visits, it means the areas are attractive (Gunn \& Var, 2002; Swarbrooke, 2002). According to Victor (1989), "attraction" is the basic motivation of tourists and recreationists to visit tourism sites. The prior goal of constructing Cultural and Creative Parks was to reinforce participation; therefore, the construction of attraction is important.

Frost-Kumpf (2001) suggested that Cultural Districts should be based on the following purposes: revive specific areas in cities to enhance their attraction, offer facilities, jobs, and settlement opportunities required by art organizations, integrate art in communities, and provide the public with artistic activities. Therefore, Cultural and Creative Parks must have various characteristics to strengthen attraction.

\subsection{Attitude CBA Model}

Attitude is a persistent learning reaction toward specific subjects. Breckler (1984) developed the "ABC model" ( $\mathrm{ABC}$ model of attitudes), and proposed three attitude elements: affective component, behavioral or conative component, and cognitive component. According to the interpretation of McLeod (2009), the three elements in the model are normally connected and the order changes according to the external factors.

Before visiting sites, most consumers search for travel information, and thus, have some cognition of the places that interest them, which leads to the behavioral intention to visit the areas, meaning affection is generated until they visit the places. Thus, this study explores Cultural and Creative Parks by the CBA attitude model, as proposed by Solomon (2002) (Lin, 2006; Engel, Blackwell \& Miniard, 1995):

- Cognition: consumers' perception, belief, and knowledge of Cultural and Creative Parks.

- Behavior: consumers' behavioral intention of Cultural and Creative Parks; meaning the possibility to adopt certain actions or participate in actions.

Affection: consumers' overall feelings and emotion toward Cultural and Creative Parks.

\subsection{Behavioral Segmentation}

Smith (1956) indicated that "segmentation" is based on market demand. Therefore, different factors should classify customers into homogeneous sub-markets with certain demands and similar preferences, in order to adjust the products and marketing. Most studies suggested that market segmentation variables include geography, demographic variables, psychological variables, and behavioral variables (Wells and Prensky, 1996; Chang, 2004; Boone and Kurtz, 2005; Lin, 2006; Huang, 2007).

Based on Kotler and Keller (2005), markets are heterogeneous, and consist of different consumer groups. According to buyers' characteristics and demands, complicated markets can be divided into several smaller and homogeneous markets, where any two clusters are based on different degrees of preference. Kotler (2003) suggested that behavioral segmentation means to segment a market into different groups according to buyers' knowledge, attitude, use, reaction, and product behavior. Therefore, from the perspective of behavioral variables, this study segments consumers according to preference for Cultural and Creative Parks, and explores the differences of two clusters.

\section{Research Hypotheses}

\subsection{Relationship between Cultural Creative Products and the Attraction of Cultural and Creative Parks}

Product design is based on differential creativity, which is an essential element in the market (Creusen \& Schoormans, 2005). Norman (2004) suggested that packaging and product design should be unique in order to attract consumers to creative products, and consider them particularly attractive. Bahn, Lee, Nam, and Yun (2009) indicated that the physical dimensions of products are the key attraction elements for people's emotions and attention. Thus, the uniqueness of cultural creative products should reinforce the attraction to Cultural and Creative Parks. Based on above, this study proposes the following hypothesis:

H1: Cultural creative products significantly enhance the attraction of Cultural and Creative Parks. 


\subsection{Relationship between Historic Buildings and Monuments and the Attraction of Cultural and Creative Parks}

In the travel motivation theory, Foster (1985) mentioned that cultural education motivation refers to visiting historic relics and museums, learning cultural related things, and enhancing the attraction for visitors. Smith (1989) suggested that tourism attractions of history, historic relics, art, and buildings are extremely critical attractive elements. Kozak (2002) also indicated that the main travel motivation includes cultural factors, which refer to visiting historic and cultural sites. Lew (1987) suggested that the attraction of tourism sites consist of landscapes, participation, memories, services, and facilities, which can satisfy tourists. Therefore, the Council for Cultural Affairs, Executive Yuan (2002) has completely preserved several idle historic buildings and constructed Cultural and Creative Parks with historic monuments to attract visitors. Based on above, this study proposes the following hypothesis:

H2: Historic buildings and historic monuments significantly enhance the attraction of Cultural and Creative Parks

\subsection{Relationship between Creative Markets and the Attraction of Cultural and Creative Parks}

"Bazaars" are eastern markets or regular trading places with many shops and stands to sell and buy goods; therefore, various products are available. According to local cultural customs, bazaars are places to collect products or conduct trade between buyers and sellers, and usually offer performing programs and entertaining activities (The Oxford English dictionary,1989). This combination of bazaar and creativity successfully attracts tourists (Peter \& Weiermair, 2000).

The rise of creative markets provide platforms for creative designers to more flexibly and freely make and sell their creative products without the limitation of rental stores or types of channels. Hence, many young people participate in experimental creation in creative markets on holidays, which develops the clustering effect of creators and attracts the public (Council for Cultural Affairs, Executive Yuan, 2008). Based on above, this study proposes the following hypothesis:

H3: Creative markets significantly enhance the attraction of Cultural and Creative Parks

\subsection{Relationship between the Performing Activities and Attractions of Cultural and Creative Parks}

William (1997) suggested that festivals are an important attraction factor to attract visitors, as they include a relationship among the meanings of the activity, the environment, and social culture, which allows tourists to approach traditional culture and demonstrates regional value. Therefore, performing activities are factors that enhance visitor participation (Saleh \& Ryah, 1993; Childress \& Cromption, 1997). Saleh and Ryah (1993) indicated that the characteristics of activities attract visitors, and include the activity programs and features of the neighborhood.

Based on Hinch (1996), local festivals attract tourists, and are the most direct and specific promotion of local culture, as local cultural features are specifically displayed and performed to draw the attention of the public. Hu and Ritchie (1993) suggested that the attraction of destinations consists of tourist sites and festivals. For instance, the Chiayi Cultural and Creative Park is based on "innovation of traditional art", which enhances attraction by planning art activities and triggers the development of the park (Ministry of Culture, 2013). Thus, this study proposes the following hypothesis:

H4: Performing activities significantly enhance the attraction of Cultural and Creative Parks

\subsection{Relationship between the Attractions of Cultural and Creative Parks and Consumers' Cognition of Cultural and Creative Parks}

Mayo and Jarvis (1981) indicated that the attractions of destinations are associated with the decision-making processes and benefits desired by tourists; attraction is a comparison between the relative importance of benefits, as expected by individuals, and the benefits that can be provided by the destinations, as perceived by individuals. The attractions of Cultural and Creative Parks change tourists' views and cognition of the parks (Hu \& Ritchie,1993). Based on the previous statement, this study proposes the following hypothesis:

H5: The attraction of Cultural and Creative Parks significantly enhances consumers' cognition of Cultural and Creative Parks

\subsection{Relationship between the Attractions of Cultural and Creative Parks and Consumers' Behavior of Cultural and Creative Parks}

Past research suggested that attraction is the main factor for tourists to visit sites (Chi et al., 2013); hence, attraction is important to enhance tourists' visits. The attraction of Cultural and Creative Parks influence people's 
revisit intentions (Wu \& Tian,2016). Chen and Tsai (2007) defined behavioral intention as tourists' intention to revisit the same destinations or the intention to recommend the destinations to others.

According to Leiper (1990), attraction is the measurement of the intensity of the attractors, meaning the internal attraction that influences tourists' behavior. Attraction draws tourists' attention, and is the driving force for their visit, thus, tourists appreciate, stay, taste, and experience the things at the destinations (Getz, 1991). Therefore, the attractions of Cultural and Creative Parks strengthens tourists' intentions to visit the parks. Based on above, this study proposes the following hypothesis:

H6: The attractions of Cultural and Creative Parks significantly enhance consumers' behavior of Cultural and Creative Parks

\subsection{Relationship between the Attractions of Cultural and Creative Parks and Consumers' affection for Cultural and Creative Parks}

Gartner, Chappelle, and Girard (1996) indicated that recreationists' impressions of sites consist of three dimensions: affection, cognition, and intention. Consumers develop affection according to the impact of the sites (Hallmann \& Breuer, 2010). Lee (2001). Hou, Lin, and Morais (2005) suggested that attraction is the key factor for affective attachment to sites. Lin and Morais (2005) studied cultural tourism, and realized that site attractions directly influenced the travelers' affective attachment toward certain sites. Based on above, this study proposes the following hypothesis:

H7: The attraction of Cultural and Creative Parks significantly enhances consumers' affection for Cultural and Creative Parks

\subsection{Consumers' Attitude Model of Cultural and Creative Parks}

Regarding the relationship among the three elements of the attitude CBA model, Hawkins (2002) indicated that the three elements stimulate each other. Lutz (1991) proposed the Tricomponent attitude model to emphasize the relationship among cognition, affection, and behavior. The low involvement CBA model, as proposed by Solomon (2002), can be applied to study tourism in Cultural and Creative Parks, as follows:

The Low Involvement Hierarchy (CBA) model means consumers have cognition of products or brands, and subsequently have the behavior of use; after use, they develop affection toward the products (Lin, 2002). In the attitude hierarchy, consumers do not prefer certain products or brands, meaning they construct their comments according to limited resources, and after actual purchase or use of products, they generate preference affection (Bruicker, 1979).

Thus, low involvement customers do not broadly search for information, they tend to make purchase decisions through limited cognition, and finally, have affection (Sanchez - Franco \& Rondan - Cataluna, 2010).

Before visiting certain places, most consumers search for local travel information, and thus, have cognition that triggers their behavioral intention to visit the sites; however, affection is not developed until they visit and experience the places. Therefore, the CBA model is more suitable for Cultural and Creative Parks. Thus, this study conducts verification by CBA, and proposes the following hypotheses:

H8: Consumers' cognition of Cultural and Creative Parks significantly enhances behavior in Cultural and Creative Parks

H9: Consumers' behavior in Cultural and Creative Parks significantly enhances their affection of Cultural and Creative Parks

\subsection{The impact of Preference For Cultural and Creative Parks on the Attitude Behavior Model}

Loyalty can be divided into behavioral and psychological dimensions: the behavioral dimension means the frequency of tourists' participation in specific activities, facilities, and service receiving, as well as the consistency of repeated participation, while the psychological dimension is tourists' affective preference (Backman \& Crompton, 1991; Dick \& Basu, 1994 ).

Based on the views of several scholars (Backman \& Crompton, 1991; Baloglu, 2001, 2002; Petrick, 2004), tourists with high or real loyalty have stronger attachment and revisit behavior, meaning they always visit specific sites; when low loyalty tourists' attachment and revisit intention are low, it means they easily become curious and tend to visit other tourist sites. Therefore, will consumers with different degrees of preference for Cultural and Creative Parks have different attitudes and behavior? This is the key point of this study.

Thus, this study divides consumers into two groups according to their preferences for Cultural and Creative Parks, and proposes the following hypothesis: 
H10: Groups with different degrees of preferences for Cultural and Creative Parks show significant difference on path intensity

\section{Research Design and Results Analysis}

\subsection{Research Framework}

This study first collects related theories and literature as the base of the research framework, and focuses on Cultural and Creative Parks for empirical research. By questionnaire survey, this study collects the primary data to explore the impact of the characteristics of Cultural and Creative Parks on attraction, and analyzes the impact of the attraction to Cultural and Creative Parks according to the three CBA model effects of attitude and the differences of different groups (see Figure 1).

\subsection{Research Method and Procedures}

This study first designs a draft of questionnaire according to previous theories and literature, conducts pretesting by interviews, and modifies the questionnaires to lead to the formal content. This study treats people at least 15 years old in Taiwan as the subjects. Convenient sampling is conducted by questionnaires distributed by the interviewer, and 800 questionnaires are the samples.

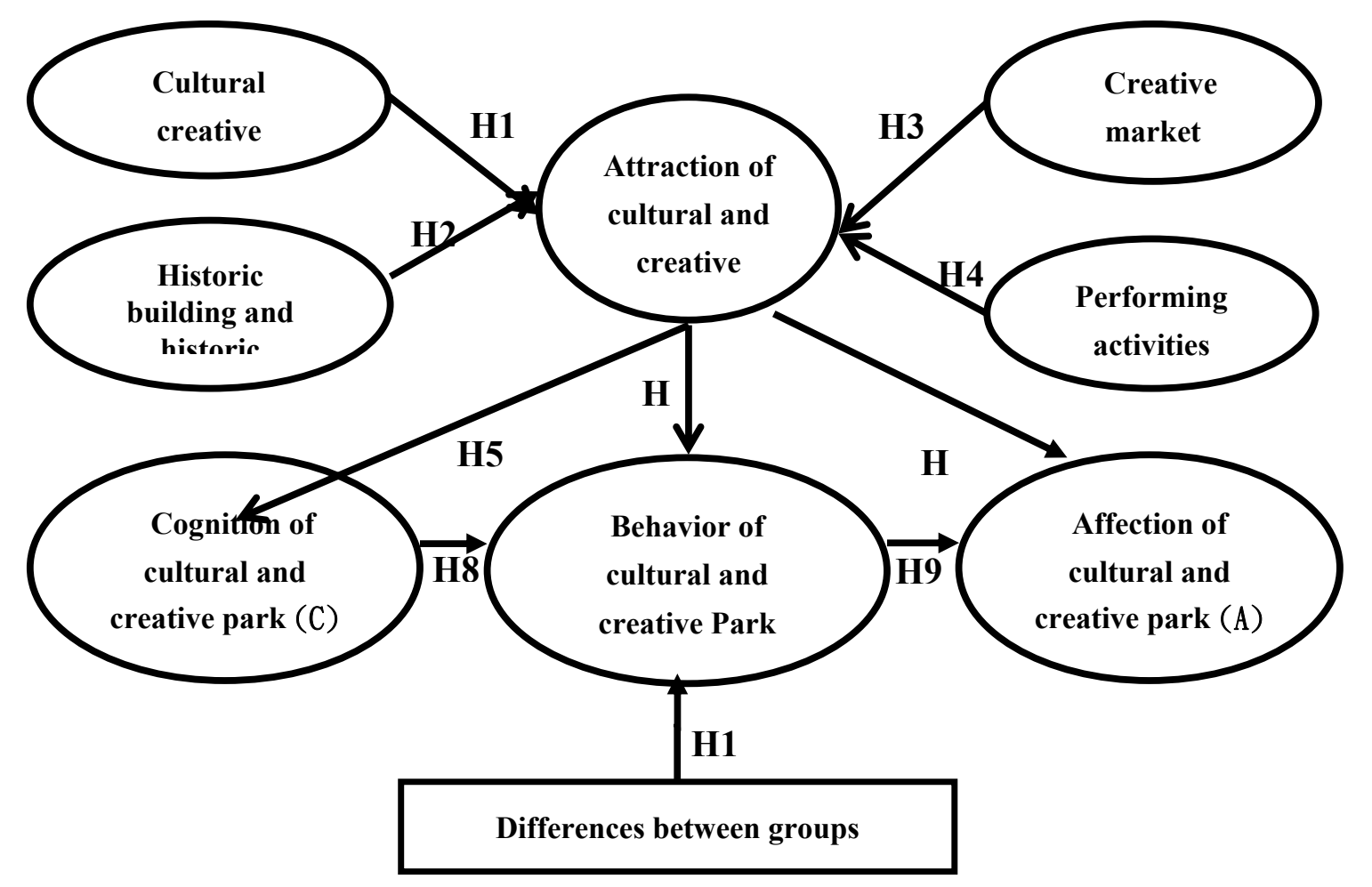

Figure 1. Research framework

\section{Research Results}

\subsection{Sample Structure}

This study treats the visitors of Cultural and Creative Parks as subjects, and by convenient sampling, distributes 800 questionnaires. After deleting 12 invalid questionnaires, this study obtains 788 valid questionnaires, for a valid return rate of $98.5 \%$. According to analysis of the retrieved samples (see Table 5), regarding personal data, most samples are females (50.1\%), regarding age, most are aged $25 \sim 34$ and the percentage is $38.6 \%$, while aged $35 \sim 44$ is $25.4 \%$; regarding residential place, most live in central Taiwan and the percentage is $34.6 \%$, followed by southern Taiwan and percentage is $33.0 \%$; regarding education, most are graduated from university (college) and the percentage is $43.9 \%$, followed by senior high school (vocational school) at $35.7 \%$; regarding occupation, most are from the manufacturing industry and the percentage is $21.2 \%$, followed by the information technology industry and the percentage is $20.2 \%$; regarding average monthly income, most are NTD\$10,001 30,000 and 
the percentage is $29.8 \%$, followed by $\operatorname{NTD} \$ 30,001 \sim 50,000$ and the percentage is $24.7 \%$; regarding preference for Cultural and Creative Parks, "yes" is the most and the percentage is $81.1 \%$.

\subsection{Reliability and Validity Analysis of the Formal Questionnaires}

This study assesses the reliability and validity of the questionnaire by Cronbach's $\alpha$ and factor analysis. According to current behavioral research, regarding the most commonly used reliability and validity measures, Cronbach's $\alpha>0.7$ has high reliability. In this study, Cronbach's $\alpha$ of the dimensions are more than 0.7 , and items of total correlation coefficients are higher than 0.5 . Therefore, the total reliability of questionnaire in this study is acceptable.

Regarding analysis of the validity of the questionnaire, by factor analysis, this study tests the convergent validity of the questionnaire. According to analysis, the variables of each dimension can be generalized as one factor, with an Eigenvalue higher than 1. Factor loading of the variables in the dimensions are higher than 0.5 , and the cumulative explained variance is higher than $50 \%$, which demonstrates the convergent validity of the questionnaire.

In this study, the $\mathrm{CR}$ of the latent variables of the dimensions are $0.8595 \sim 0.8764$, and are higher than 0.6 , meaning the internal consistency of the dimensions in this study is acceptable. The AVE of the latent variables is 0.5053 0.5576, which are higher than 0.5 and match the standard. In other words, all items in the dimensions have a high degree of consistency (Fornell \& Larcker,1981)(See Table 1).

Table 1. Analysis of the Reliability and Validity of the Official Questionnaire

\begin{tabular}{|c|c|c|c|c|c|c|c|c|}
\hline Factor & Mean & $\begin{array}{l}\text { Item-to-total } \\
\text { correlation } \\
\text { coefficient }\end{array}$ & $\begin{array}{l}\text { Factor } \\
\text { loading }\end{array}$ & Eigenvalue & $\begin{array}{l}\text { Cumulative } \\
\text { explained } \\
\text { variation } \%\end{array}$ & $\begin{array}{l}\text { Cronbach } \\
\alpha \\
\text { value }\end{array}$ & $\begin{array}{l}\text { Component } \\
\text { reliability } \\
(\mathrm{CR})\end{array}$ & $\begin{array}{l}\text { Average } \\
\text { variance } \\
\text { extracte } \\
\text { d (AVE) }\end{array}$ \\
\hline \multicolumn{9}{|c|}{ Cultural creative products } \\
\hline $\begin{array}{l}\text { Cultural } \\
\text { creative } \\
\text { products in } \\
\text { the park can } \\
\text { be identified }\end{array}$ & 5.4188 & .605 & .745 & \multirow{6}{*}{3.141} & \multirow{6}{*}{52.354} & \multirow{6}{*}{.818} & \multirow{6}{*}{.8693} & \multirow{6}{*}{.5259} \\
\hline $\begin{array}{l}\text { Cultural } \\
\text { creative } \\
\text { products in } \\
\text { the park are } \\
\text { high-quality }\end{array}$ & 5.6079 & .586 & .730 & & & & & \\
\hline $\begin{array}{l}\text { Cultural } \\
\text { creative } \\
\text { products in } \\
\text { the park are } \\
\text { creative }\end{array}$ & 5.5406 & .587 & .728 & & & & & \\
\hline $\begin{array}{l}\text { Cultural } \\
\text { creative } \\
\text { products in } \\
\text { the park have } \\
\text { cultural } \\
\text { characteristic } \\
\text { s }\end{array}$ & 5.4645 & .585 & .724 & & & & & \\
\hline $\begin{array}{l}\text { Cultural } \\
\text { creative } \\
\text { products in } \\
\text { the park are } \\
\text { diverse }\end{array}$ & 5.6282 & .565 & .709 & & & & & \\
\hline $\begin{array}{l}\text { Cultural } \\
\text { creative }\end{array}$ & 5.5939 & .560 & .705 & & & & & \\
\hline
\end{tabular}




\begin{tabular}{|c|c|c|c|c|c|c|c|c|}
\hline $\begin{array}{l}\text { products of } \\
\text { the park have } \\
\text { local features }\end{array}$ & & & & & & & & \\
\hline Historic building & $\mathrm{g}$ and histor & mont & & & & & & \\
\hline $\begin{array}{l}\text { Buildings in } \\
\text { the park can } \\
\text { be the } \\
\text { landmarks of } \\
\text { tourist }\end{array}$ & 5.6383 & .638 & .775 & & & & & \\
\hline $\begin{array}{l}\text { Buildings in } \\
\text { the park can } \\
\text { trigger } \\
\text { industrial } \\
\text { economy }\end{array}$ & 5.6383 & .598 & .711 & & & & & \\
\hline $\begin{array}{l}\text { Buildings in } \\
\text { the park can } \\
\text { attract the } \\
\text { visitors }\end{array}$ & 5.6904 & .594 & .706 & & & & & \\
\hline $\begin{array}{l}\text { Buildings in } \\
\text { the park have } \\
\text { local cultural } \\
\text { features }\end{array}$ & 5.5622 & .579 & .704 & 3.032 & 50.534 & .804 & .8595 & .5053 \\
\hline $\begin{array}{l}\text { Buildings in } \\
\text { the park have } \\
\text { different } \\
\text { characteristic } \\
\text { s }\end{array}$ & 5.6459 & .571 & .688 & & & & & \\
\hline $\begin{array}{l}\text { The buildings } \\
\text { in the park } \\
\text { have } \\
\text { historical } \\
\text { meanings }\end{array}$ & 5.5647 & .537 & .677 & & & & & \\
\hline Creative market & & & & & & & & \\
\hline $\begin{array}{l}\text { Creative market } \\
\text { of the park } \\
\text { combines } \\
\text { business and art }\end{array}$ & $\begin{array}{ll}\mathrm{et} & \\
\mathrm{k} & \\
& \\
& \end{array}$ & .636 & .775 & & & & & \\
\hline $\begin{array}{l}\text { Creative market } \\
\text { of the park } \\
\text { combines with art } \\
\text { festivals }\end{array}$ & 5.6751 & .561 & .711 & & & & & \\
\hline $\begin{array}{l}\text { Creative market } \\
\text { of the park often } \\
\text { holds the art } \\
\text { activities }\end{array}$ & $\begin{array}{ll}\text { et } & \\
\text { it } & \\
\mathrm{rt} & \\
& \end{array}$ & .552 & .706 & 3.032 & 50.534 & 0.804 & .8595 & .5053 \\
\hline $\begin{array}{l}\text { Creative market } \\
\text { of the park has } \\
\text { the capacity of art } \\
\text { creation }\end{array}$ & 5.7208 & .550 & .704 & & & & & \\
\hline $\begin{array}{l}\text { Creative market } \\
\text { of the park sells } \\
\text { featured } \\
\text { hand-made } \\
\text { products }\end{array}$ & $\begin{array}{ll}\text { et } & \\
\text { ls } & \\
& \\
& \end{array} .5343$ & .536 & .688 & & & & & \\
\hline $\begin{array}{l}\text { Creative market } \\
\text { of the park has }\end{array}$ & 5.5102 & .527 & .677 & & & & & \\
\hline
\end{tabular}




\begin{tabular}{|c|c|c|c|c|c|c|c|c|}
\hline $\begin{array}{l}\text { unique desig } \\
\text { style }\end{array}$ & & & & & & & & \\
\hline \multicolumn{9}{|c|}{ Performing activities } \\
\hline $\begin{array}{l}\text { Performing } \\
\text { activities of tl } \\
\text { park can attra } \\
\text { the tourists } \\
\text { characteristics }\end{array}$ & $\begin{array}{l}\text { he } \\
\text { act } 5.5279 \\
\text { by }\end{array}$ & .587 & .733 & \multirow{6}{*}{3.051} & \multirow{6}{*}{50.856} & \multirow{6}{*}{0.807} & \multirow{6}{*}{.861} & \multirow{6}{*}{.5082} \\
\hline $\begin{array}{l}\text { Performing } \\
\text { activities of tl } \\
\text { park can crea } \\
\text { industrial value } \\
\text { performing art }\end{array}$ & $\begin{array}{l}\text { he } \\
\text { of } 5.6383 \\
\text { of }\end{array}$ & .584 & .731 & & & & & \\
\hline $\begin{array}{l}\text { Performing } \\
\text { activities of th } \\
\text { park can cultiva } \\
\text { art creators }\end{array}$ & he 5.6269 & .569 & .718 & & & & & \\
\hline $\begin{array}{l}\text { Performing } \\
\text { activities of tl } \\
\text { park includes tl } \\
\text { performance } \\
\text { large-scale stage }\end{array}$ & $\begin{array}{l}\text { he } \\
\text { he } 5.6380 \\
\text { of }\end{array}$ & .559 & .709 & & & & & \\
\hline $\begin{array}{l}\text { Performing } \\
\text { activities of th } \\
\text { park can enhan } \\
\text { image of the city }\end{array}$ & 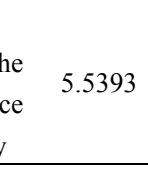 & .556 & .705 & & & & & \\
\hline $\begin{array}{l}\text { The park al } \\
\text { holds performin } \\
\text { activities }\end{array}$ & $\begin{array}{ll}\text { so } & \\
\text { ng } & 5.4429 \\
\end{array}$ & .530 & .680 & & & & & \\
\hline \multicolumn{9}{|c|}{ Attraction of Cultural and Creative Park } \\
\hline $\begin{array}{l}\text { Performing } \\
\text { activities of } \\
\text { the Cultural } \\
\text { and Creative } \\
\text { Park are } \\
\text { attractive }\end{array}$ & 5.5647 & .630 & .771 & \multirow{5}{*}{3.072} & \multirow{5}{*}{51.195} & \multirow{5}{*}{0.809} & \multirow{5}{*}{.8626} & \multirow{5}{*}{.5118} \\
\hline $\begin{array}{l}\text { Festival of } \\
\text { the Cultural } \\
\text { and Creative } \\
\text { Park is } \\
\text { attractive }\end{array}$ & 5.6206 & .591 & .736 & & & & & \\
\hline $\begin{array}{l}\text { The Cultural } \\
\text { and Creative } \\
\text { Park has } \\
\text { characteristic } \\
\text { s }\end{array}$ & 5.6447 & .564 & .714 & & & & & \\
\hline $\begin{array}{l}\text { Buildings in } \\
\text { the Cultural } \\
\text { and Creative } \\
\text { Park are } \\
\text { attractive }\end{array}$ & 5.4987 & .564 & .709 & & & & & \\
\hline $\begin{array}{l}\text { Creative } \\
\text { market of the } \\
\text { Cultural and } \\
\text { Creative Park } \\
\text { creative }\end{array}$ & 5.4962 & .536 & .689 & & & & & \\
\hline
\end{tabular}




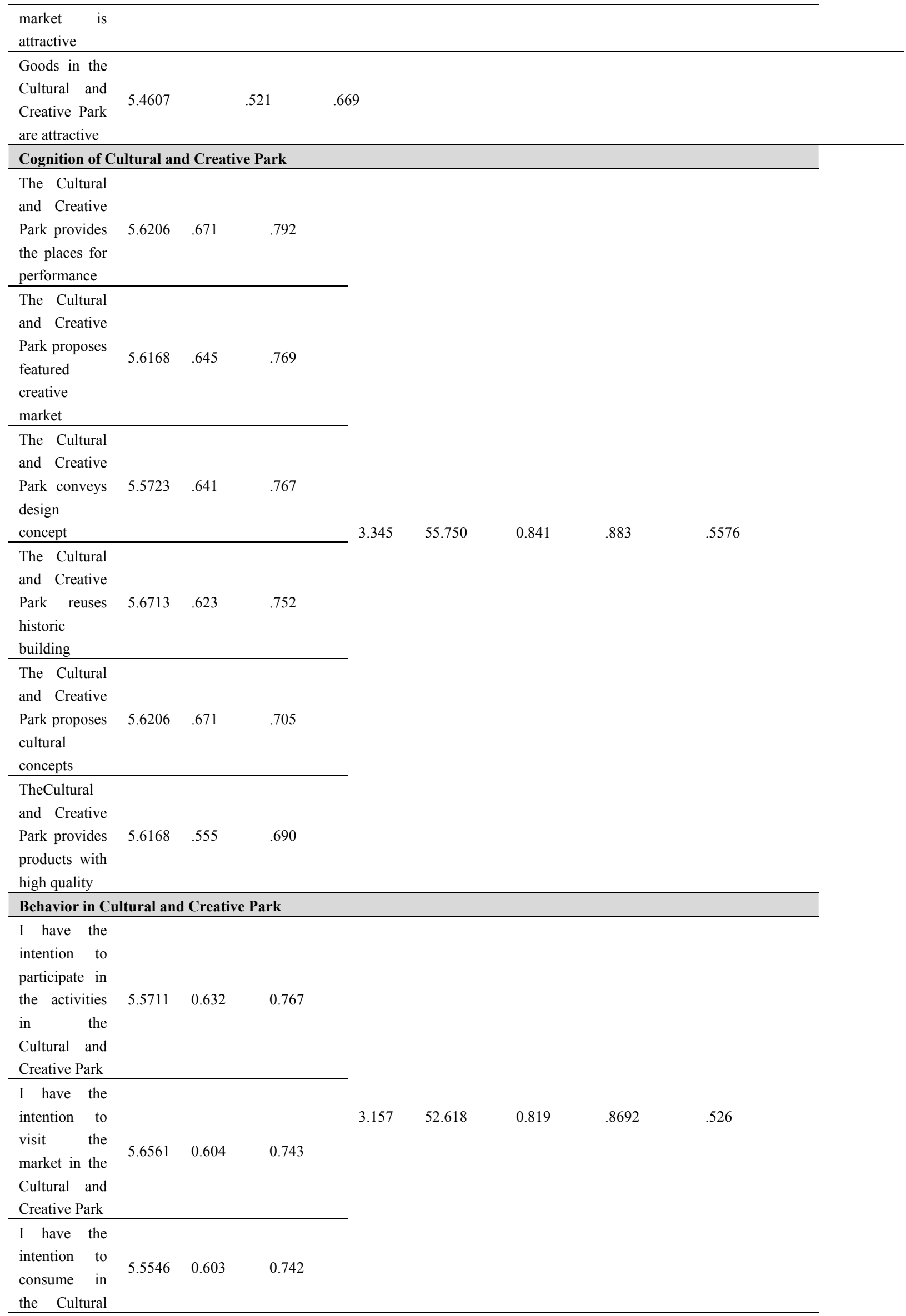




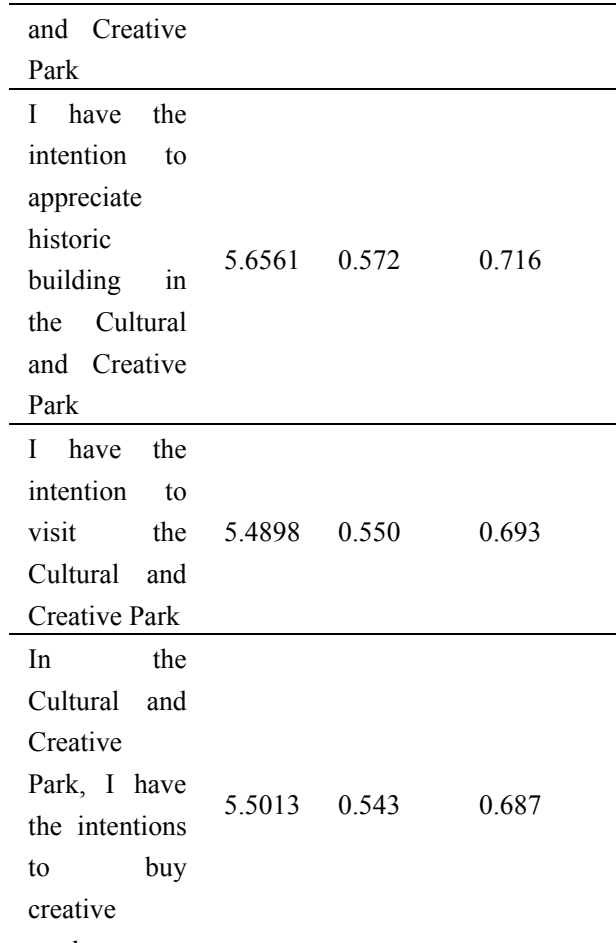

products

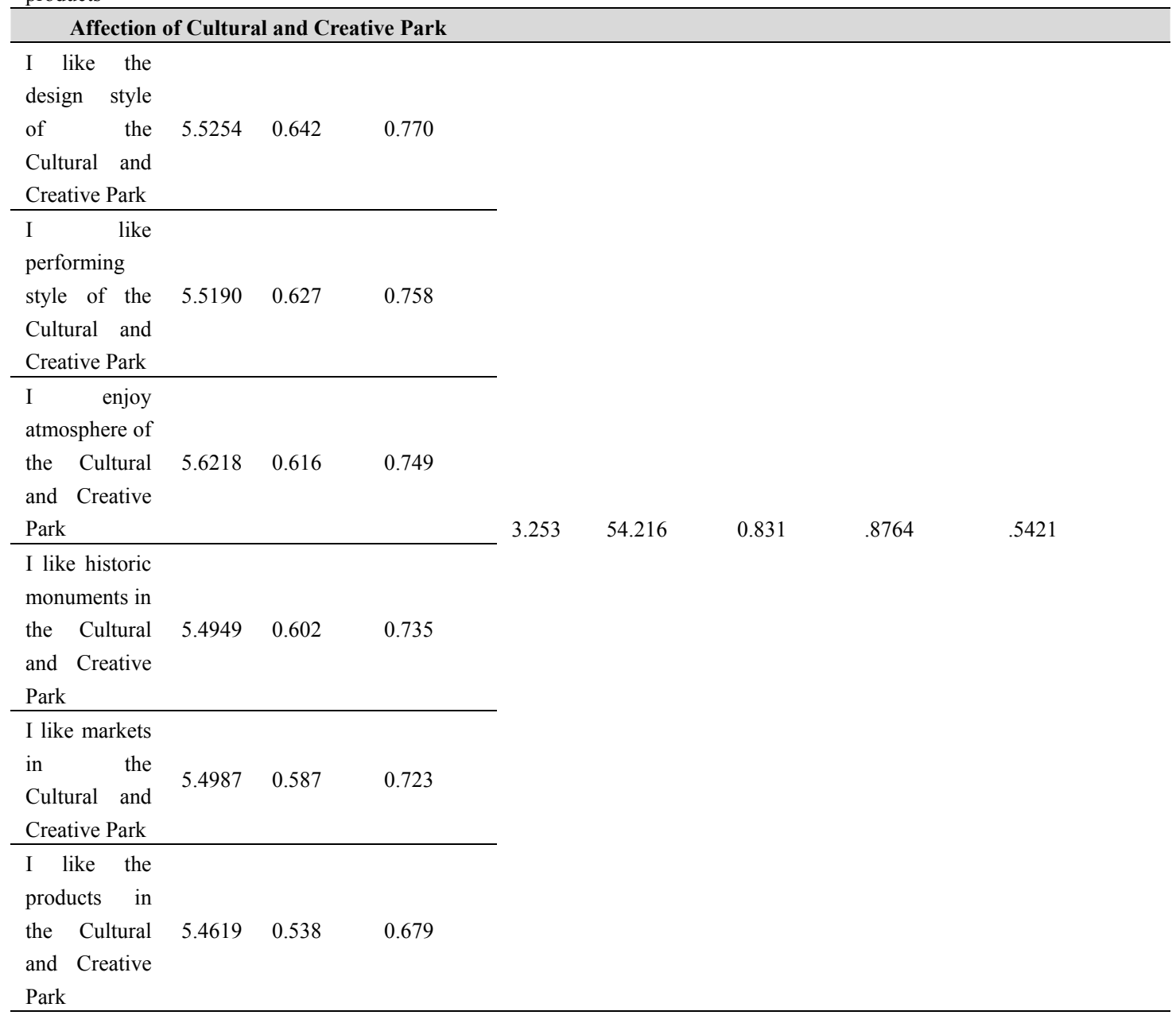

\subsection{Confirmatory Factor Analysis (CFA)}


In order to validate the efficiency of the dimensions, this study adopts AMOS to conduct CFA on cultural creative products, historic buildings, historic monuments, creative markets, performing activities, attractions of the Cultural and Creative Park, cognition of the Cultural and Creative Park, the behavior of the Cultural and Creative Park, and affection for the Cultural and Creative Park.

According to the model proposed by Carmines and MacIver (1981), the fit measurement should match the standard, and the ratio between the chi-square value and freedom should be $\leqq 3$. RMR and RMSEA are lower than 0.05, and GFI, AGFI, NFI, and CFI are higher than 0.9 (Bagozzi \& Yi, 1988; Joreskog \& Sorbom, 1989). Sharma (1996) suggested that when GFI is higher than 0.8, it matches the fit. Segars and Grover (1993) suggested that when AGFI $>0.8$, it is acceptable. According to the findings, regarding the total model fit measures, $\chi 2 / \mathrm{df}$ is 1.395 , GFI is 0.933 , AGFI is 0.920 , NFI is 0.913 , RFI is 0.901 , CFI is 0.973 , RMSEA is 0.020 , and RMR is 0.022 . Thus, the fit of the measurement model is acceptable, meaning the measures have construct validity and measurement efficiency.

\subsection{Multi-group Competing Model Comparison and Analysis}

Regarding the valid retrieved 788 questionnaires; according to the items of preference for Cultural and Creative Parks, this study divides them into two groups, where 639 prefer Cultural and Creative Parks while 149 do not enjoy Cultural and Creative Parks.

By AMOS, this study compares the two groups of Cultural and Creative Parks, in order to determine whether the different degrees of preference for Cultural and Creative Parks have significant mediating effect on the relationship among the dimensions. Regarding the fit measures of the competing model, $\chi 2$ / df is 2.239 , GFI is 0.800 , AGFI is 0.780 , NFI is 0.725 , RFI is 0.711 , CFI is 0.825 , and RMSEA is 0.040 , which shows that the fit of competing model of this study is acceptable. Analytical results and descriptions are shown in Table 2:

(1). According to the result of $\mathrm{T}$ testing, the two groups have significant difference on the intensity of the path from cultural creative products to attraction of Cultural and Creative Parks (H1) ( $\mathrm{t}=4.681)$. The impact intensity of the group that does not like Cultural and Creative Parks in this path is higher than those who enjoy Cultural and Creative Parks, meaning that the group who does not like Cultural and Creative Parks perceive the attraction of Cultural and Creative Parks by cultural creative products.

(2). The two groups have significant difference on the impact intensity of the path of historic buildings and historic monuments to the attraction of Cultural and Creative Parks (H2) ( $\mathrm{t}=4.655)$. The impact intensity of the group who does not like Cultural and Creative Parks in this path is higher than those who enjoy Cultural and Creative Parks, meaning that when selecting parks, the group who does not like Cultural and Creative Parks perceive the attraction of the parks according to historic buildings and monuments.

(3). The two groups have significant differences on the impact intensity of the path from creative market to the attraction of Cultural and Creative Parks (H3) $(t=4.829)$. The group who enjoys Cultural and Creative Parks in the path has an impact intensity higher than those who do not like Cultural and Creative Parks, and the impact is positive, meaning that when selecting parks, the group who enjoys Cultural and Creative Parks are more concerned about creative markets.

(4). The two groups have significant differences on impact intensity in the path from performing activities to the attraction of Cultural and Creative Parks (H4) ( $\mathrm{t}=-2.606)$. The group who enjoys Cultural and Creative Park in this path has impact intensity higher than those who do not like parks, meaning that when selecting parks, those who enjoy Cultural and Creative Parks prefer Cultural and Creative Parks due to the performance activities.

(5). The two groups have significant difference on the impact intensity in the path from attraction of Cultural and Creative Parks to cognition of Cultural and Creative Parks (H5) ( $t=-4.79)$. The group who do not like Cultural and Creative Parks in the path show impact intensity higher than those who enjoy the parks, meaning that when selecting parks, those who do not like Cultural and Creative Parks enhance their cognition of the parks due to their attraction to Cultural and Creative Parks.

(6). The two groups have significant difference on impact intensity in the path from attraction of Cultural and Creative Parks to behavior in Cultural and Creative Parks (H6) $(\mathrm{t}=-4.315)$. Those who enjoy Cultural and Creative Parks in this path have impact intensity higher than the group who do not like Cultural and Creative 
Parks, and the impact is positive, meaning that when selecting parks, the group who enjoys Cultural and Creative Parks enhance their behavior to visit the parks due to their attraction.

(7). The two groups have significant difference on impact intensity in the path from attraction of Cultural and Creative Parks to affection for Cultural and Creative Parks (H7) $(\mathrm{t}=3.273)$. Those who do not like Cultural and Creative Parks have impact intensity in this path higher than those who enjoy Cultural and Creative Park, meaning that when selecting parks, the former enhance their affection for the parks due to their attraction.

(8). The two groups do not have significant difference on impact intensity in the path from cognition of Cultural and Creative Parks to behavior to Cultural and Creative Parks (H8) $(\mathrm{t}=0.517)$. The two groups have positive impact, meaning that the two groups enhance their behavior for parks due to their cognition.

(9). The two groups do not have significant difference on impact intensity in the path from behavior to Cultural and Creative Parks to affection for Cultural and Creative Park (H9) $(t=0.426)$. The two groups show positive impact, meaning that the two groups enhance their affection toward Cultural and Creative Parks by their behavior toward the parks.

Based on the above, the two groups show significant differences in 8 path intensities among the dimensions.

Thus, consumers who prefer or do not like Cultural and Creative Parks have significant difference in the impact intensities of most of the paths, and the two groups demonstrate the differences of the relationship structure. Therefore, H10 is partially supported, and is an important finding of this study, as shown in Table 2.

Table 2. Comparison analysis of the multi-group competing model

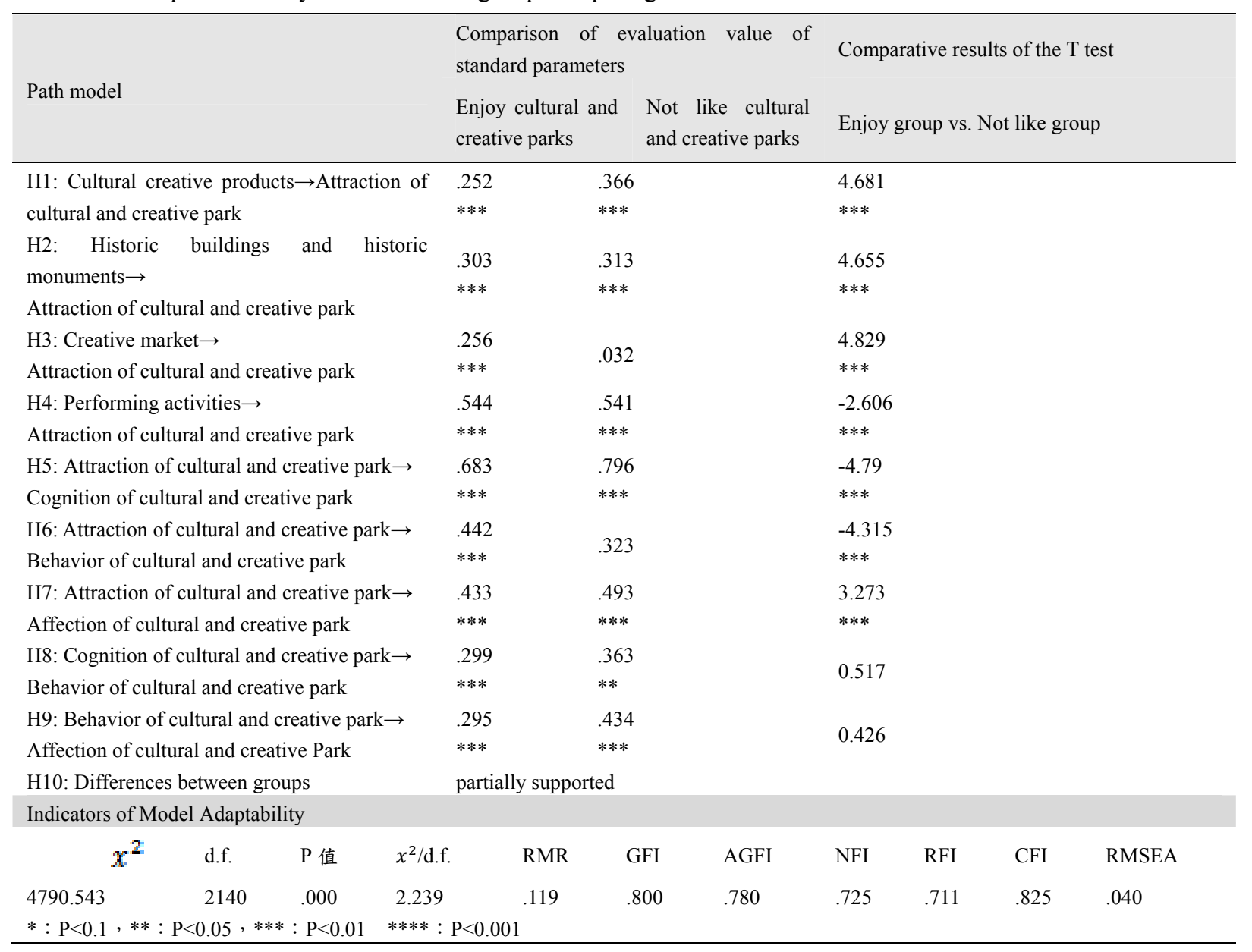

\section{Conclusion and Suggestions}

\subsection{Research Conclusions}


From the perspectives of consumers, by empirical research, this study explores the impact of cultural creative products, historic buildings, historic monuments, creative markets, and performing activities on the attraction of Cultural and Creative Parks; as well as the impacts of the attraction of Cultural and Creative Parks on cognition, behavior, and affection for Cultural and Creative Parks. This study constructs a relationship model and compares the differences of the groups who enjoy and do not enjoy Cultural and Creative Parks, and proposes an important framework concept and research tool for academia and business circles, which have academic and practical value. The results are shown, as follows:

(1). Regarding the comparison of the four independent variables on attraction to Cultural and Creative Parks, the two groups show significant impact of performing activities on attraction to Cultural and Creative Parks, meaning that when selecting parks, the two groups enhance their preferences and attractions due to the performance activities in Cultural and Creative Parks; and this is particularly significant for those who enjoy Cultural and Creative Parks.

(2). Regarding the impact of the attraction of Cultural and Creative Parks on attitude CBA, the two groups show significant impact of attraction of Cultural and Creative Parks on cognition of the parks, meaning that the two groups enhance their cognition of the parks due to their attraction; and this is particularly significant for those who do not enjoy Cultural and Creative Parks.

(3). Regarding the difference of the two groups in the attitude CBA model, the impact of cognition on behavior is more significant. Those who do not enjoy Cultural and Creative Parks have the behavior to visit the parks according to the cognition of Cultural and Creative Parks, and after visiting the parks, they develop affection.

\subsection{Managerial Implications}

According to the results of the linear structural model of this study, there are similarities and differences between these two groups. Thus, this study proposes managerial directions and suggestion, as follows:

Consumers who enjoy Cultural and Creative Parks pay attention to the following four characteristics of Cultural and Creative Parks: performing activities, historical buildings monuments, creative markets, and cultural creative products. Among others, consumers pay more attention to performance activities. Therefore, Cultural and Creative Parks should include performing activities, which can cultivate art creators and develop industrial value for performance arts, which will result in attracting consumers.

The group who does not enjoy Cultural and Creative Parks are more concerned about the attraction of the parks, and they develop cognition of Cultural and Creative Parks. Thus, if parks reinforce the four characteristics, consumers will have cognition according to the impact of the attraction of four features. Those who do not prefer Cultural and Creative Parks have prior cognition of the parks, which triggers their behavioral intention to visit, and they develop affection, thus, the group who does not enjoy Cultural and Creative Parks might be more interested in the parks.

\subsection{Research Limitations and Suggestions to Future Studies}

According to the characteristics of Cultural and Creative Parks in Taiwan, this study explores their possible impact on attraction to the park. However, there are still characteristics that have not been discussed, which could enhance attraction to Cultural and Creative Parks. Therefore, this study suggests that future research can include more variables to validate the extension effect of the concept model. In addition, this study focuses on the top five Cultural and Creative Parks in Taiwan; however, as the scales of the parks are different and the operational effects are varied, this research is limited. This study suggests that future research can conduct comparative analysis on different types of Cultural and Creative Parks to enhance the precision of research results.

\section{References}

Backman, S. J., \& Crompton, J. L. (1991). Differentiating between high, spurious, latent, and low loyalty participants in two leisure activities. Journal of Park and Recreation Administration, 9(2), 1-17.

Bahn, S., Lee, C., Nam, C. S., \& Yun, M. H. (2009). Incorporating affective customer needs for luxuriousness into product design attributes. Human Factors and Ergonomics in Manufacturing \& Service Industries, 19(2), 105-127.

Bianchini, F. (1993). Cultural policy and urban regeneration: The west European experience. Manchester: Manchester University Press.

Borg, Jan van der, Costa, P., \& Gotti, G., (1996). Tourism in European heritage cities. Annals of Tourism Research, 23(2), 306-321. 
Breckler, S. J. (1984). Empirical validation of affect, behavior, and cognition as destine components of attitude. Journal of Personality and Social Psychology, May, 1191-1205

Chang, T. C., Milne, S., Fallon, D., \& Pohlmann, C. (1996). Urban heritage tourism: the global local nexus. Annals of Tourism Research, 23(2), 284-305. http://dx.doi.org/10.1016/0160-7383(95)00064-X

Charles, L. (2000). The Creative City: A Toolkit for Urban Innovators. London, Earthscan Publications, 56.

Chen, C. H., \& Tsai, D. C. (2007). How destination image and evaluative factors affect behavioral intentions? Tourism Management, 28, 1115-1122. http://dx.doi.org/10.1016/j.tourman.2006.07.007

Cheng, K. F. (2013). Consumer Behavior: Life and Marketing (2nd ed.), Taipei: Future Career publishing corporation.

Childress, R. D., \& Cromption, J. L. (1997). A comparison of alternative direct and discrepancy approaches to measuring quality of performance at a festival. Journal of Travel Research, 24(2), 43-57.

Foster , D. W. (1985). Travel and Tourism Management Houndmills. London: Palgrave Macmillan.

Frost-Kumpf, H. A. (1998). Cultural Districts: The Art as a Strategy for Revitalizing Our Cities., Americans for the Arts: Washington, DC.

Frost-Kumpf, H. A. (2001). Cultural districts: arts management and urban development. Unpublished paper.

Getz, D. (1991). Festival, Special Events and Tourism. New York: Van Nostrand Reinhold.

Gunn, C. A. \& Var, T. (2002). Tourism Planning: Basics, Concept, Cases (4th ed.), New York: Routledge. http://dx.doi.org/10.1016/0160-7383(80)90057-2

Handa, R. (1999). Against arbitrariness: architectural signification in the age of globalization. Design Studies, 20(4), 363-380. http://dx.doi.org/10.1016/S0142-694X(98)00041-6

Herbert, D. T. (1995). Heritage Place: Leisure and Tourism in Herbert, Heritage, Tourism and Society. New York: Mansel.

Hilary Anne Frost Kumpf. (2001). Cultural districts: Arts management and urban redevelopment. Unpublished paper.

Hinch, T. D. (1996). Urban tourism: perspectives on sustainability. Sustainable Tourism, 4(2), 95-100. http://dx.doi.org/10.1080/09669589608667261

Hou, J. S., Lin, C. H., \& Morais, D. B. (2005). Antecedents of attachment to a cultural tourism destination: The case of Hakka and non-Hakka Taiwanese visitors to Pei-Pu, Taiwan. Journal of Travel Research, 44, 221-223. DOI: $10.1177 / 0047287505278988$

Hu, Y., \& Ritchie, J. R. (1993). Measuring destination attractiveness: A contextual approach. Journal of Travel Research, Fall, 2-34.

Hu, Y., \& Ritchie, J. R. B. (1993) Measuring destination attractiveness: A contextual approach. Journal of Travel Research, 3202, 25-34.

Korgaonkar, P. K., \& Moschis P. G. (1982). An experience study of cognitive dissonance, product involvement, expectations, performance and consumer judgment of product performance. Journal of Advertising, 11, 32-44.

Kotler, P. (1997). Marketing Management: Analysis, Planning, Implementation, and Control (9th ed.). Prentice-Hall, Inc.

Kotler, P. (2002). Marketing Management Millennium Edition (10 $0^{\text {th }}$ ed.), Boston Pearson: Custom Publishing.

Kotler, P., \& Keller, K. L. (2005). Marketing Management. NJ: Prentice-Hall.

Kozak, M. (2002). Comparative analysis of tourist motivations by nationality and destinations. Tourism Management, 23(3), 221-232. http://dx.doi.org/10.1016/S0261-5177(01)00090-5

Krugman, H. E. (1967). The measurement of advertising involvement. Public Opinion Quarterly, 30(4), 583-596. http://dx.doi.org/10.1086/267457

Kuo, H. L., Huan, T. C., Thongma, W., Guntoro, B., Tsai, C. F., \& Chen, K. Y. (2011). The relationships among tourism image, Perceived quality, Place attachment, Tourist satisfaction and revisit intention- a case of international tourists in Thailand tourism night market.1st World Research Summit for Tourism and Hospitality, 10-13. 
Lee, J., Park, D. H., \& Han, I. (2008). The effect of negative online consumer reviews on product attitude: An information processing view. Electronic Commerce Research and Applications, 73, 341-352.

Leiper, N. (1990). Tourist attraction systems. Annals of Tourism Research, 17(3), 367-384. http://dx.doi.org/10.1016/0160-7383(90)90004-B

Lew, A. (1987). A framework of tourist attraction research. Annals of Tourism Research, 4, 533-575. http://dx.doi.org/10.1016/0160-7383(87)90071-5

Lin, J. H. (2002). Marketing. Taipei: Hwa Tai Publishing.

Lin, R. T. (2009). Design friendship into modern products. In Joan C. Toller (ed.), Friendships: types, cultural, psychological and social (Chapter 3). New York: Nova Science Publishers, Inc.

Ministry of Culture. (2013). 2013 Cultural news, Taiwan.

Ministry of Culture. (2014). Operation and management of top five cultural and creative parks in 2014, Taiwan.

Moalosi, R., Popovic, V., \& Hickling, H. A. (2010). Culture-orientated product design, international. Journal of Technology and Design education, 20, 175-190. http://dx.doi.org/10.1007/s10798-008-9069-1

Montgomery, J. (2003). Cultural quarters as mechanisms for urban regeneration. Part 1: Conceptualizing cultural quarters. Planning, Practice and Research, 18(4), 293-306.

Montgomery, J. (2004). Cultural quarters as mechanisms for urban regeneration. Part 2: A review of four cultural quarters in the UK, Ireland and Australia. Planning, Practice and Research, 19(1), 3-31.

Oliver, R. L. (1981). Measurement and evaluation of satis faction processes in retailing settling. Journal of Retailing, 57(3), 25-48.

Peterson, G. L. (1974). Evaluating the quality of the wilderness environment: Congruence between perception and aspiration. Environment and Behavior, 6(2), 169-193.

Ray, A. (1973). Marketing communication and the hierarchy of effects. New Model for Mass Communication Research, (2), 147-176.

Rosenberg, M. J., Hovland, C. I., McGuire, W. J., Abelson, R. P., \& Brehm, J. W. (1960). Attitude Organization and Change. New Haven: Yale University Press.

Saleh, F., \& Ryah, C. (1993). Jazz and knitwear: Factors that attracts to festivals. Tourism Management, 14(4), 289-297.

Sanchez Franco, M. J., \& Rondan Cataluna, F. J. (2010). Virtual travel communities and customer loyalty: Customer purchase involvement and web site design. Electronic Commerce Research \& Applications, 9(2), 171-182. http://dx.doi.org/10.1016/j.elerap.2009.05.004

Santagata, W. (2006). Cultural districts and their role in developed and developing countries. Handbook of the Economics of Art and Culture, 1, 1101-1119. http://dx.doi.org/10.1016/S1574-0676(06)01031-3

Smith, V. L. (1989). Hosts and Guest: The Anthropology of Tourism. Philadelphia University of Pennsylvania Press.

Smith, W. R. (1956). Product differentiation and market segmentation as alternative marketing strategies. Journal of Marketing, 21(3), 3-8. http://dx.doi.org/10.2307/1247695

Solomon, M. R. (2002). Consumer Behavior Buying, Having and Being. NJ: Prentice Hall.

Swarbrooke, J. (2002). The Development and Management of Visitor, Oxford: Butterworth-Heinemann.

The American Marketing Association. (2008). Retrieved March 19, 2013, from http://www.marketingpower.com/aboutama/documents/american\%20marketing\%20association\%20releases \%20new\%20definition\%20for\%20marketing.pdf

The Oxford English Dictionary. (1989). Blue Leather Edition Twenty-Volume Set. Oxford University Press, USA.

Throsby, D. (2001). Economics and Culture. Press: Cambridge University. http://dx.doi.org/10.1017/CBO9781107590106

Victor, T. C. (1989). Marketing implications for attractions. Tourism Management, 3, 229-232.

Wells, W. D., \& Prensky, D. (1996). Consumer Behavior. NY: John Wiley and Sons Inc.

William, F. T. (1997). Global Tourism: The Next Decade. London: Butterworth-Heinemann. 
Williams, R. (1981) Culture, London: Fontana.

Wu, S. I., \& Tian, M. L. (2016). Exploring the impacts of characteristics of cultural and creative park and attraction by CBA attitude model. The 2016 Cross-Strait Technology, Humanity Education and Academy-Industry Cooperation Conference. The 2016 Conference on Sustainable Operation and Development.

Yair, K., Press, M., \& Tomes, A. (2001). Crafting competitive advantage: Crafts knowledge as a strategic resource. Design Studies, 22(4), 377-394. http://dx.doi.org/10.1016/S0142-694X(00)00043-0

Yair, K., Tomes, A., \& Press, M. (1999). Design through marking: Crafts knowledge as facilitator to collaborative new product development. Design Studies, 20(6), 495-515.

Zeithaml, L., Berry, L. \& Parasuraman, A. (1996). The behavioral consequences of service quality. Journal of Marketing, 60(4), 31-46. http://dx.doi.org/10.2307/1251929

\section{Copyrights}

Copyright for this article is retained by the author(s), with first publication rights granted to the journal.

This is an open-access article distributed under the terms and conditions of the Creative Commons Attribution license (http://creativecommons.org/licenses/by/4.0/). 